\title{
Motivation for Conjugality in Couples Life Cycle and Its Relation to Happiness and Satisfaction
}

\author{
José de Abreu-Afonso, Isabel Leal, Vera Proença \\ Departamento de Psicologia Clínica e da Saúde, Ispa-IU, Lisboa, Portugal \\ Email: joseabreuafonso@netcabo.pt
}

Received 29 June 2015; accepted 23 August 2015; published 26 August 2015

Copyright (C) 2015 by authors and Scientific Research Publishing Inc.

This work is licensed under the Creative Commons Attribution International License (CC BY). http://creativecommons.org/licenses/by/4.0/

cC) (i) 0 pen Access

\begin{abstract}
The present research intended to study the motivation in couples along the life cycle and its relation to happiness and satisfaction. 185 heterosexual couples, separated into seven groups, participated in this study. Motivation was assessed using MS Motivation Scale (Rempel, Holmes, \& Zanna, 1985; Portuguese version by Abreu-Afonso \& Leal, 2009), a Unique Index Scale for Assessment of Marital Global Satisfaction and a Unique Index Scale for Assessment of Happiness. We concluded that, although during marriage cycle men and women's motivation does not suffer large fluctuations, there is a decrease in women's intrinsic motivations both personal and perceived. However, small differences can be reported when comparing both genders within each group. For marital satisfaction, perceived motivation is as important as personal motivation, but only in what concerns intrinsic motives. In a general overview, happiness seems to be a broader concept since the results of this variable are less complex than those concerning satisfaction.
\end{abstract}

\section{Keywords}

Motivation, Satisfaction, Happiness, Conjugality

\section{Introduction}

During marriage, couples are often subjected to contradictory forces, which lead them to seek for help to deal with crises that may arise. Family therapists have realized the essentiality of contextualizing those crises in the couples' life cycle, assuming that the transition phases are the most vulnerable (Haley, 1984). In couples life we can consider various stages, characterized and refined by different authors (Carter \& McGoldric, 1989; Neighbourgh, 1985; Relvas, 2004), each of them requiring the accomplishment of certain developmental tasks, and 
associated with some specific risks.

The present work aims to study motivation in those different stages of marriage and its relation with couples satisfaction and happiness. For such, it is important to review how marriage evolves and how motivation can be influenced.

\subsection{Couple Life Cycle}

When new couples are formed, some problems can be raised, from the bonding process to the relation with the family of origin, or even with the deidealization of the spouse. When those tasks are not correctly achieved, latent incompatibilities may be revealed. Most of the separations occur at this stage.

The birth of a child brings complex changes to the couple, transforming it into a family, with the emergence of the first triangle. The romantic relationship is relegated to a second plane, emerging conflicts with the education of children. Paradoxical social pressures are felt and the first sexual difficulties appear. In general, the accomplishing of this stage will lead to the strengthening of the bond between the spouses.

However, if conflicts are not resolved, they can increase when children reach adolescence. This new stage will coexist with the existential crisis of the couple, probably between 40 and 50 years old, and the need to evaluate life and redefine its meaning. They also have to deal with their own parents' aging. All those predicaments may lead to the ending of chronically poor relationships.

Another important period is the departure of children and the readaptation of living together as a couple. In this phase, couples face their parents' death, and generally, retirement takes place, with eventual loss of prestige. The need to find another meaning for life becomes stronger. Depression and psychosomatic complaints are common when the couple is unable to support each other and create new goals (Waldemar, 1998). Another nodal point is the closeness of death of either spouse.

Failure or difficulty in accomplishing the tasks that each stage demands can create couple instability or discomfort, lower marital satisfaction and, often, motivates disruption.

\subsection{Motivation and the Self-Determination Theory}

When studying couples, researchers have often considered one or more dimensions seeking to establish relationships between them. One widely studied variable that has shown to be vital to comprehend and assist couples seeking for help and that arouse in several studies is motivation (Aimé, Sabourin, \& Valois, 2000; Aron, Norman, Aron, McKenna, \& Heyman, 2000; Bernstein, 1990; Blais, Sabourine, Boucher, \& Vallerand, 1990; Deci \& Ryan, 1985, 2000, 2008; DeHart, Pelham, Fiedorowicz, Carvalho, \& Gabriel, 2011; Gable \& Impett, 2012; Gaine \& La Guardia, 2009; Impett, Gable, \& Pelau, 2005; Impett et al., 2010; Knee, Lonsbary, Canevello, \& Patrick, 2005; Knee, Patrick, Vietor, Nanayakkara, \& Neighbors, 2002; Kogan, Impett, Oveis, Hui, Gordon, \& Keltner, 2010; La Guardia \& Patrick, 2008; Murray, 2005; Patrick, Knee, Lonsbary, \& Canevello, 2007; Rempel, Holmes, \& Zanna, 1985; Seligman, Fazio, \& Zanna, 1980; Vallerand, 2000).

Motivation is what moves people to act, think and develop. It can be defined as "a dispositional tendency or as a context-specific orientation" (Gaine \& Guardia, 2009: p. 184).

The approach to motivation has expanded rapidly, exceeding the scope of biology, defended by trends like behaviourism and psychoanalysis. Many perspectives were developed, some pointing the person as the centre of her own motivation, others focused on external rewards and their role in motivation (Mayer, Faber, \& Xu, 2007). This is undoubtedly a preview of the current concepts of intrinsic and extrinsic motivation, currently influencing much of research in this area.

Our work takes into account Deci and Ryan's Self Determination Theory (SDT) (1985, 2000, 2008; Ryan \& Deci, 2000), that support the existence of different types of motivation. Despite other theories that defend motivation as a unitary concept that varied in amount, Deci and Ryan (2000) have suggested that the style of motivation is a more important issue.

Self-determined motivation has the aim to provide a person the capability to have intentional behaviours. However, to achieve a self-determinated motivation, people have to pursuit the fulfilment of three basic psychological needs. The higher the level of fulfilment of those needs, the more self-determined is the motivation (Patrick et al., 2007; Vallerand, 2000). Therefore, the psychological needs-competence, relatedness and autonomycan be defined as "innate psychological nutriments that are essential for ongoing psychological growth, integrity and well-being” (Deci \& Ryan, 2000: p. 229). Competence is the predisposition to influence environment ob- 
taining positive outcomes. Relatedness refers to the need to connect with others (Ryan, Kuhn et al., 1997, as cited in Deci \& Ryan, 2000). Autonomy is a sense of integration and freedom of the self (Deci \& Ryan, 2000). When those needs are not fulfilled, people often engage in alternative paths, as defensive or self-protective processes like developing substitute motives, non-autonomous styles and rigid behaviour patterns. However, substitute motives do not fulfil the psychological needs; instead, they provide a substitute fulfilment (Deci \& Ryan, 2000). Therefore, a more self-determined motivation is a more intrinsic motivation, whereas a less selfdetermined motivation is a more extrinsic motivation, being controlled by extrinsic reasons.

Kesser and Ryan (1993, 1996, as cited in Ryan \& Deci, 2000) have distinguished between intrinsic and extrinsic goals. Intrinsic goals are enablers of psychological needs fulfilment (Baumeiter \& Leary, 1995, as cited in Sheldon, Ryan, Deci, \& Kasser 2004) being beneficial in numerous contexts and supportive of autonomy and competence in the pursuing an activity that, by itself, is pleasurable. The intrinsically motivated activities are spontaneous and come from people's inner interest (Story, Hart, Stansson, \& Mahoney, 2009), having therefore an internal locus of causality (Heider, 1958, as cite in Deci \& Ryan, 2000). People have to feel competent and self-determined, to be intrinsically motivated. Nevertheless, we do not always engage in actions that we like, and in those cases, people seem to be motivated by external motives (La Guardia \& Patrick, 2008). Extrinsic goals usually appear from a lack of basic needs fulfilment, and seem to be intimately related with negative feelings and behaviours (Kasser \& Ryan, 2001, as cited in Sheldon et al., 2004). When external reward is inserted into an intrinsic motivated activity, locus of causality will shift from internal to external. Extrinsic rewards can induce a serious risk of reducing intrinsic motivation (Deci, Koestner, \& Ryan, 1999), because people no longer feel the activity as spontaneous, causing a decrease of the level of autonomy by giving value to the goal itself (Aron, Aron, \& Norman, 2002; Deci \& Ryan, 1983, 2000, 2008).

Human beings have a natural tendency to dedicate more time and interest in actions chosen by them, as well as for integration, assimilating objectives, values and behaviours consistent with a sense of self (Bernstein, 1990; Patrick, Knee, Lonsbary, \& Canevello, 2007) accommodating them as their own, in a process denominated internalization (Deci \& Ryan, 2000, 2008). For Deci and Ryan (2008), the focus of internalization shifts from the classical differentiation intrinsic/extrinsic to autonomous/controlled. Therefore, people present a more autonomous motivation when pursuing intrinsic goals, whereas, in the presence of extrinsic goals the motivation is more controlled. The authors also suggested the existence of amotivation, related with a lack of intent to behave, due to an absence of efficacy or control and with negative outcomes (Deci \& Ryan, 2000). Different types of regulation-external regulation, introjection, identification, and integration-are located in a continuum that goes from more controlled aiming a specific external reward to less controlled and more spontaneous and pleasurable form of motivation (Deci et al., 1999a, as cited in Deci \& Ryan, 2000; Deci \& Ryan, 2008).

\subsection{Motivation in Close Relationships}

Close relationships have a very important function in people's lives, influencing how a person thinks, fell and act (Andersen, Reznik \& Mazella, 1996, Baldwin, Carrel, \& Lopez, 1990, Mikulincer, 1998, as cited in Gable \& Impett, 2012). Motivation will have a large influence on the establishment and maintenance of those relationships, the choice of the partner, the quality of everyday relational behaviours, and in the understanding of marital satisfaction (Aimé et al., 2000; Bernstein, 1990; Blais, et al., 1990; Deci \& Ryan, 2000, 2008; Gaine \& La Guardia, 2009; Impett et al., 2005; Impett et al., 2010; Knee et al., 2002; Kogan, et al., 2010; Patrick et al., 2007; Rempel et al., 1985). Marital satisfaction can be defined as "people's global subjective evaluation about the quality of their marriage” (Li \& Fung, 2011: p. 246). Therefore, the style of motivation that each partner presents on engaging and maintaining a relationship is important to realize the quality of the marital bond (Gaine \& La Guardia, 2009).

Different types of motivation are associated with important and various behavioural, cognitive and affective consequences (Deci \& Ryan, 1985; Vallerand, 2000). Self-determined motivation, lead to more adaptive behaviours and eventually greater positive affective reactions. It is, therefore, reasonable that this interpretation can be applied to the maintenance of relationships, affecting the relational behaviours (Blais, et al., 1990).

Engaging in a relationship can be motivated by intrinsic rewards, directly mediated by the relationship or by the partner, such as the pleasure of day-to-day couple's activities, or by extrinsic rewards, receiving from others outside the relationship, but mediated by involvement with the partner (social status, social connections and business, etc.) (Rempel et al., 1985). 
Kogan, et al. (2010) found that when people are motivated to respond to the other person's needs, without expecting benefits in return, the sacrifice is felt like intrinsically rewarded. A relationship is more likely to endure and be satisfactory when the motivation is more intrinsic (Rempel et al., 1985). Extrinsic motivations presumably will weaken the character of intrinsic motives and, consequently, reduce feelings of love for the partner (Seligman et al., 1980). Despite the fact that external motivations may undermine the relationship, extrinsic motives can be perceived by the subject in light of specific feelings, and interpreted as intrinsic (Rempel et al., 1985). Blais, et al. (1990) have demonstrated that extrinsic motivation is not necessarily bad for the quality of relationships, depending on the nature of the self-determined extrinsic motivation.

Several authors (Blais, et al., 1990; Knee et al., 2005; Patrick et al., 2007) advocate that intrinsic and autonomous reasons for being in a relationship, will provide a more adaptive behaviours, mainly with regard to dealing with conflict, such as, engaging in active coping strategies. Therefore, a more autonomous motivation is synonymous of more positive outcomes, higher level of satisfaction and more positive relationships (Bernstein, 1990; Deci \& Ryan, 2000, 2008), leading to the growth of the relationship.

As said before, marital relationship is a process of interdependence, therefore is conceptually relevant to take into account the styles of motivation of each partner and their mutual influence. It is not only important our personal motivation, as well as, the partners' motivation that we perceive. Couples, who perceive behaviour to correspond to what they expected, experience greater relational happiness (La Guardia \& Patrick, 2008). These perceptions will facilitate the recognition of different levels of convergence and divergence between couples' functioning. Both partners may have different emotional experiences, since both have individual differences mediating the perception the same behaviour. The quality of the relationship can be more affected by the perception of the behaviour, than by the concrete behaviour (Blais et al., 1990). The studies of DeHart et al. (2011) suggested that there is a link between our self-perception and the perception that we have from what other perceive of us. However, the authors argue that the way we evaluate the other, influences our own perception of ourselves. Blais et al. (1990) showed that both partners' motivational style predicted personal feelings of satisfaction with the relationship, through their impact on perceptions of the couple's adaptive behaviour. Aimé et al. (2000) found that couples composed by individuals with congruent and self-determined motivation presented high levels of satisfaction. The same authors suggested that congruent and self-determined motivated couples, when compared with no congruent motivated couples, or congruent but little self-determined motivated couples, have higher satisfaction. Over time, couples tend to change from a more self-determined and congruent style, to a more incongruent and less self-determined, leading marital satisfaction to decrease significantly.

The establishing and rooting of trust relies deeper on beliefs about the partners' motivation, influencing feelings of confidence and the success of the relationship. Faith in the relationship is related with the perception that the partner is intrinsically motivated. However, these feelings may be weakened by the attribution of extrinsic motives (Rempel et al., 1985). Peoples' will to engage in various tasks in their relationships, is a predictor of their commitment, satisfaction, intimacy and vitality within the relationship (Gaine \& La Guardi, 2009). Aron et al. (2000), also suggested that sharing novel and arousing activities would increase the relationship's quality.

Women appear as a key role in romantic relationships, having a large responsibility in relationship satisfaction and motivation. Women's motivational style is the only predictor of women's satisfaction, and it is also a good predictor of men's satisfaction, playing a great role in the development and maintenance of the quality of the relationships (Blais et al., 1990). For various reasons, women seem to rely less exclusively than men on the romantic implications of intrinsic assignment (Rempel et al., 1985). Feelings of love in women appear to be connected with instrumental motivations, as well as, with intrinsic motivations.

\section{The Present Study}

Our study is part of a larger project examining different aspects of couples' dynamics during life. In what concerns motivation, the reviewed literature and previous researches have shown some trends and similarities. There is a clear association between the style of motivation and the quality of the marital relationship (Bernstein, 1990; Blais, et al., 1990; Deci \& Ryan, 2000, 2008; Knee, et al., 2002; Kogan, et al., 2010; Patrick et al., 2007; Rempel et al., 1985). Some authors emphasize the influence of variables such as the expected behaviour (Blais et al., 1990; Bradbury \& Fincham, 1987; Marman, 1979, Miller et al., 1986; Schaefer \& Burnett, 1987 as cited in Blais et al., 1990), the role played by women in the relationship (Blais et al., 1990), or the congruence of motivation styles (Aimé et al., 2000). 
However, and despite the overall production on the topic of motivation, there have been few studies investigating family processes across the life cycle, which is essential for a more sophisticated understanding of the marital relationship. This shortage suggests a direction that the present study seeks to overcome. We still hope that this research may eventually shed light on aspects that were far less clear in previous research, notably by overcoming fragilities in many other studies related with the constitution of the samples.

Another of our goals is to try to overcome a limitation of many previous studies that investigated chronological periods, being subject to various biases, such as the idealization of the first years of married life, when evaluated retrospectively.

Therefore, we have defined the variables used in this study: motivation styles, marital satisfaction, marital happiness, gender and time of marital relationship.

We will investigate the evolution of the intrinsic and extrinsic motivational factors along marriage, namely in the nodal points of crisis/change in the couple life cycle, as well as gender differences in what concerns the relation between marital satisfaction and happiness and motivation style. More specifically an exploratory, comparative and correlational study between different stages of the couple's life and between genders will be held, to enable to respond to the following questions:

1) Is the motivation that leads a couple to stay together throughout life always the same? How is personal motivation (intrinsic and extrinsic) and the perceived motivation (intrinsic and extrinsic) vary over the life cycle considering the subjects' gender?

2) How does satisfaction vary over time and between genders? How do the changes in the lifelong motivation style, influence satisfaction in both genders? How does the perceived partner's motivation (intrinsic and extrinsic) influence satisfaction in men and women? Which style of motivation is related to higher satisfaction?

3) How does happiness vary over time and between genders? How does motivation relate to happiness? What kind of motivation is related to greater happiness? Are there changes in different stages of the life cycle and between genders? How does change of lifelong motivation influences the perception of happiness?

\section{Method}

\subsection{Participants}

This is a convenience sample, collected in schools, businesses, health centres, community centres etc. through a "snowball" sampling. We wanted to cover a large sample-in Lisbon and its surrounding area. The participants are 370 individuals, 185 couples, 138 married and 47 cohabiting. The groups were made based on family cycle literature (Carter \& McGoldric, 1989; Neighbourgh, 1985; Relvas, 2004). However, a new group was taken into account. We came across several couples that still had their adult children living in with them. This raised a question about the effect in the couple, which is expected to be in a different stage. Therefore, we decided to separate this specific group taking into account:

1) The new couples/Couples without children: married or living together up to 4 years (inclusive), having no children from current or previous marriage living with them. All couples with more than 5 years of marriage and couples with less than 4 years of marriage where children were excluded.

2) Couples with young children: Couples with children from the current relationship with age up to 5 years, regardless of the number of years of marriage/cohabitation. Couples with children from other marriages were not included, because we intend to evaluate the impact of the birth of a child of both.

3) Couples with school-age children: Couples with children aged between 6 and 12 years (inclusive), regardless of years of marriage. Couples with children at this age who also have older children from the current marriage or another, living with them, were excluded.

4) Couples with adolescents: Couples whose children are between 13 and 19 years old. Couples with children at this age, but also with older children from current and previous marriages, living with them, were excluded.

5) Couples whose children have left home: Couples whose all children have left home less than four years inclusive.

6) Couples with adult children staying at home: Couples with older children (over age 23) who still live at home. We excluded couples whose children were aged between 20 and 23 (university attendance, cannot be considered adults or adolescents)

7) Couples in Old Age: Couples without children at home and at least one member of the couple is aged 60 years or older. All couples were included regardless of the number of marriages and children from each mar- 
riage.

Participants presented significant differences in age among all groups, in women and men $[F(6)=158.893$, $p=0.000, \mathrm{~F}(6)=85.262, p=0.000]$ : the age of the couples is higher along the different phases. In the five groups, men are significantly older than women: New couples (difference of 3.5 years, $\mathrm{t}(29)=-3.796, p=$ 0.000 ), Couples with young children (difference of $3,67, \mathrm{t}(39)=-4.783, p=0.000$ ), Couples with adolescents (difference 2.60, t (37) $=-4.374, p=0.000)$, Couples whose children have left home (difference 3.5, $\mathrm{t}(29)=$ -3.796, $p=0.001$ ), and Couples with adult children staying at home (difference 2.08, $\mathrm{t}(24)=-3.436, p=$ 0.002). In the groups: Couples with school age children (difference of $1.69 \mathrm{t}(25)=-1.541, p=0.136)$ and Couples in Old Age (difference 0.66, t $(17)=0.809, p=0.430$ ) differences are not statistically significant.

Schooling is high in both sexes and a large percentage of subjects in all groups have secondary and college education. However, there are noteworthy differences between men and women in two groups: the Couples with adult children staying at home, schooling is higher for fathers than mothers (in $42 \%$ of the couples, fathers have higher education than mothers; in $46 \%$ schooling is identical and only in $12 \%$ of the couples mothers have a higher education than fathers: Wilcoxon, $p=0.034$ ), whereas in the group of Couples with school-age children are mothers who have a higher education (54\% of mothers have higher schooling, 19\% of fathers have higher schooling and in $27 \%$ of cases it is identical Wilcoxon $p=0.034)$. Comparing the seven groups in what concerns schooling, we observe significant differences in the education of women from the group Couples without children and the last three groups (Couples whose children have left home, Couples in old age and Couples with adult children staying at home) with these ones less educated than women without children.

In what concerns the duration of the relationship in couples living together and married ones, in each group, there are no significant differences. Looking at the results in married couples we observed that in the groups Couples with young children and Couples with school age children the average number of children is lower (between 1.24 and 1.50) than in other groups in which the average ranges between 1.96 and 2.36.

\subsection{Procedure}

The study was approved by the ethics committee of ISPA. The questionnaires were distributed and delivered in several services in the Lisbon metropolitan area. All data was collected through a "snowball” system, taking 18 months to compose a sample of 596 valid questionnaires (298 couples). From this initial group, 185 couples were selected for the present study. All the participants in the study provided their informed consent.

\subsection{Measures}

Sociodemographic Data. The Sociodemographic Questionnaire assessed a variety of variables providing sociological information about the sample, and allowed the definition of our groups.

Marital Satisfaction. Satisfaction was measured using a Unique Index Scale for Assessment of Marital Global Satisfaction. Participants were asked to respond to a unique question-How satisfied are you with your relationship?-in a 5-point scale going from Very Unsatisfied to Very Satisfied.

Marital Happiness. Happiness was assessed using a Unique Index Scale for Assessment of Happiness. Participants were asked to respond to a unique question-How happy is your relationship? - in a 5-point scale going from Very unhappy to Very happy.

Motivation. Motivation was assessed using MS Motivation Scale (Rempel, Holmes \& Zanna, 1985)—(Portuguese version translated and adapted by “athor" 2009). The present scale has 24 items answered in a 9-point scale that goes from nothing to completely. The participant has to respond twice from two different perspectives: first, a personal perspective that allows assessing personal motivation; second from his/her perspective of the spouse/partner's motivations, allowing to assess perceived motivation. The scales are divided in two factors: extrinsic and intrinsic motivation; allowing to assess four factors for each participant: intrinsic personal motivation, intrinsic perceived motivation, extrinsic personal motivation and extrinsic perceived motivation.

\section{Results}

In order to compare the seven groups' responses to the two items regarding the degree of happiness and satisfaction with the relationship, we used the Kruskal-Wallis test. These two questions also worked as an intra-group comparison, assessing within each of the seven groups if there were significant differences between the elements 
of the couple, resorting to the nonparametric Wilcoxon test.

To compare the seven groups in the intrinsic motivation variable (personal and partner reasons) it was possible the use of a parametric test (Anova One Way) given that the variables in study are quantitative and the different groups have normal distributions or no severe deviations in these variables. Furthermore, the variances were homogenous. For intra group comparison (female vs. male) within each of the seven groups, we used the parametric Studen's T-test for dependent samples (Table 1).

The Kruskal-Wallis test did not reveal significant differences among the seven groups in the degree of happiness of women $(\mathrm{X} 2=7.786, \mathrm{df}=6$, Sig $=0.254)$ and the degree of happiness of men $(\mathrm{X} 2=10.369, \mathrm{df}=6$, Sig $=$ 0.110). In general, the responses are focused on: "Happy" or "Very Happy". After this intergroup analysis, an intra-group analysis was carried out, exploring in each of the seven groups if there were significant differences between the degree of happiness of men and women (Table 2).

There are, in only one of the seven groups (Couples with adult children staying at home), significant differences in the degree of happiness between men and women, with a higher degree of happiness in men. In a large percentage of couples from this group, men are happier than women (44\%), with $44 \%$ of couples with an identical happiness and only $12 \%$ of couples in which women are happier than the men (Table 3).

The Kruskal-Wallis test revealed significant differences among the seven groups in the degree of satisfaction of women $(\mathrm{X} 2=21.395, \mathrm{df}=6$, Sig $=0.002)$ and detected a difference in the threshold of significance between the groups in the degree of men's satisfaction $(\mathrm{X} 2=12.303 \mathrm{df}=6$, Sig $=0.056)$. We resorted to various Mann-Whitney test to compare each pair of groups and detect which groups differ significantly. Regarding satisfaction among women we found that those from New Couples (without children) reveal a significantly higher satisfaction than women from all the other groups (sigs between 0.027 and 0.001). Significant differences were detected between the women from the group Couples whose children have left home and women from the groups Couples with young children (sig $=0.047$ ) and Couples with school-age children (sig $=0.039$ ), showing that women who no longer have children at home have a lower satisfaction than women in the other two groups.

Regarding the satisfaction of men, we detected significant differences between the men from the group New

Table 1. Degree of Happiness with the relationship: results for the seven groups and both genders.

\begin{tabular}{|c|c|c|c|c|c|c|c|c|}
\hline \multicolumn{9}{|c|}{ 1-What is the degree of happiness in your relationship? } \\
\hline & & $\begin{array}{c}\text { Very } \\
\text { unhappy }\end{array}$ & Unhappy & $\begin{array}{l}\text { Somewhat } \\
\text { unhappy }\end{array}$ & $\begin{array}{l}\text { Neither } \\
\text { happy nor } \\
\text { unhappy }\end{array}$ & $\begin{array}{l}\text { Somewhat } \\
\text { happy }\end{array}$ & Happy & $\begin{array}{l}\text { Very } \\
\text { happy }\end{array}$ \\
\hline \multirow{2}{*}{ New Couples } & Fem & $3.3 \%(1)$ & $0 \%(0)$ & $0 \%(0)$ & $10 \%(3)$ & $3.3 \%(1)$ & $36.7 \%(11)$ & $46.7 \%(14)$ \\
\hline & Male & $0 \%(0)$ & $0 \%(0)$ & $0 \%(0)$ & $0 \%(0)$ & $10 \%(3)$ & $36.7 \%(11)$ & $53.3 \%(16)$ \\
\hline \multirow{2}{*}{$\begin{array}{l}\text { Couples with small } \\
\text { children }\end{array}$} & Fem & $2.5 \%(1)$ & $0 \%(0)$ & $2.5 \%(1)$ & $5.0 \%(2)$ & $7.5 \%(3)$ & $57.5 \%(22)$ & $25.0 \%(10)$ \\
\hline & Male & $0 \%(0)$ & $0 \%(0)$ & $0 \%(0)$ & $5.0 \%(2)$ & $7.5 \%(3)$ & $57.5 \%(23)$ & $30.0 \%(12)$ \\
\hline \multirow{2}{*}{$\begin{array}{l}\text { Couples with school age } \\
\text { children }\end{array}$} & Fem & $0 \%(0)$ & $0 \%(0)$ & $3.8 \%(1)$ & $0 \%(0)$ & $7.7 \%(2)$ & $57.7 \%(15)$ & $30.8 \%(8)$ \\
\hline & Male & $0 \%(0)$ & $0 \%(0)$ & $0 \%(0)$ & $3.8 \%(1)$ & $3.8 \%(1)$ & $53.8 \%(14)$ & $38.5 \%(10)$ \\
\hline \multirow{2}{*}{$\begin{array}{l}\text { Couples with adolescent } \\
\text { children }\end{array}$} & Fem & $2.6 \%(1)$ & $2.6 \%(1)$ & $2.6 \%(1)$ & $5.3 \%(2)$ & $13.2 \%(5)$ & $50 \%(19)$ & $23.7 \%(9)$ \\
\hline & Male & $0.0 \%(0)$ & $2.6 \%(1)$ & $0.0 \%(0)$ & $13.2 \%(5)$ & $5.3 \%(2)$ & $55.3 \%(21)$ & $23.7 \%(9)$ \\
\hline \multirow{2}{*}{$\begin{array}{l}\text { Couples whose children } \\
\text { have left home }\end{array}$} & Fem & $0 \%(0)$ & $0 \%(0)$ & $25 \%(2)$ & $0 \%(0)$ & $0 \%(0)$ & $75 \%(6)$ & $0 \%(0)$ \\
\hline & Male & $0 \%(0)$ & $0 \%(0)$ & $12.5 \%(1)$ & $12.5 \%(1)$ & $0 \%(0)$ & $62.5 \%(5)$ & $12.5 \%(1)$ \\
\hline \multirow{2}{*}{ Couples in old age } & Fem & $0 \%(0)$ & $0 \%(0)$ & $5.6 \%(1)$ & $0 \%(0)$ & $0 \%(0)$ & $72.2 \%(11)$ & $22.2 \%(4)$ \\
\hline & Male & $5.6 \%(1)$ & $0 \%(0)$ & $0 \%(0)$ & $0 \%(0)$ & $5.6 \%(1)$ & $50.0 \%(9)$ & $38.9 \%(7)$ \\
\hline \multirow{2}{*}{$\begin{array}{l}\text { Couples with adult } \\
\text { children staying at } \\
\text { home }\end{array}$} & Fem & $0 \%(0)$ & $4.2 \%(1)$ & $0 \%(0)$ & $16.7 \%(4)$ & $12.5 \%(3)$ & $37.5 \%(9)$ & $29.2 \%(7)$ \\
\hline & Male & $3.4 \%(2)$ & $1.7 \%(1)$ & $0 \%(0)$ & $0 \%(0)$ & $8.0 \%(2)$ & $56.0 \%(14)$ & $32.0 \%(8)$ \\
\hline \multirow{2}{*}{ Total } & Fem & $1.6 \%(3)$ & $1.1 \%(2)$ & $3.2 \%(6)$ & $5.9 \%(11)$ & $7.6 \%(14)$ & $52.4 \%(97)$ & $28.1 \%(52)$ \\
\hline & Male & $0.5 \%(1)$ & $0.5 \%(1)$ & $0.5 \%(1)$ & $5.4 \%(10)$ & $6.5 \%(12)$ & $52.4 \%(97)$ & $34.1 \%(63)$ \\
\hline
\end{tabular}


Table 2. Degree of happiness with the relationship: comparison between women and man.

\begin{tabular}{ccccc}
\hline & $\begin{array}{c}\text { Happiness } \\
\text { Male }<\text { Fem }\end{array}$ & $\begin{array}{c}\text { Happiness } \\
\text { Male }>\text { Fem }\end{array}$ & $\begin{array}{c}\text { Happiness } \\
\text { Male = Fem }\end{array}$ & Wilcoxon \\
\hline New Couple $(\mathrm{n}=30)$ & $23.33 \%(7)$ & $33.33 \%(10)$ & $43.33 \%(13)$ & $\mathrm{Z}=-1.375, p=0.169$ \\
Couples with small children $(\mathrm{n}=40)$ & $15 \%(6)$ & $20 \%(8)$ & $65 \%(26)$ & $\mathrm{Z}=-1.101, p=0.271$ \\
Couples with school age children $(\mathrm{n}=26)$ & $7.69 \%(2)$ & $23.07 \%(6)$ & $69.23 \%(18)$ & $\mathrm{Z}=-1.027, p=0.305$ \\
Couples with Adolescent children ( $\mathrm{n}=38)$ & $28.95 \%(11)$ & $31.58 \%(12)$ & $39.47 \%(15)$ & $\mathrm{Z}=-0.202, p=0.840$ \\
Couples whose children have left home $(\mathrm{n}=8)$ & $25 \%(2)$ & $37.5 \%(3)$ & $37.5 \%(3)$ & $\mathrm{Z}=-0.412, p=0.680$ \\
Couples in old age (n= 18) & $11.11 \%(2)$ & $27.77 \%(5)$ & $61.11 \%(11)$ & $\mathrm{Z}=-0.344, p=0.731$ \\
Couples with adult children staying at home $(\mathrm{n}=25)$ & $12 \%(3)$ & $44 \%(11)$ & $44 \%(11)$ & $\mathrm{Z}=-2.012, p=0.040^{*}$ \\
Total (n= 185) & $17.83 \%(33)$ & $29.73 \%(55)$ & $52.43 \%(97)$ & $\mathrm{Z}=-2.240, p=0.025^{*}$ \\
\hline
\end{tabular}

Note: *Significant at $p<0.05$.

Table 3. Degree of satisfaction with the relationship: results for the seven groups and for both genders.

\begin{tabular}{|c|c|c|c|c|c|c|}
\hline & & \multicolumn{5}{|c|}{ 3-What is your level of satisfaction with your relationship? } \\
\hline & & $\begin{array}{c}\text { Very } \\
\text { Unsatisfied }\end{array}$ & $\begin{array}{c}\text { Very } \\
\text { Unsatisfied }\end{array}$ & $\begin{array}{c}\text { Very } \\
\text { Unsatisfied }\end{array}$ & $\begin{array}{c}\text { Very } \\
\text { Unsatisfied }\end{array}$ & $\begin{array}{c}\text { Very } \\
\text { Unsatisfied }\end{array}$ \\
\hline \multirow{2}{*}{ New Couples } & Fem & $0 \%(0)$ & $0 \%(0)$ & $6.7 \%(2)$ & $26.7 \%(8)$ & $66.7 \%(20)$ \\
\hline & Male & $0 \%(0)$ & $0 \%(0)$ & $3.3 \%(1)$ & $33.3 \%(10)$ & $63.3 \%(19)$ \\
\hline \multirow{2}{*}{$\begin{array}{l}\text { Couples with } \\
\text { small children }\end{array}$} & Fem & $0 \%(0)$ & $2.5 \%(1)$ & $5.0 \%(2)$ & $67.5 \%(27)$ & $25 \%(10)$ \\
\hline & Male & $0 \%(0)$ & $0 \%(0)$ & $5.0 \%(2)$ & $52.5 \%(21)$ & $42.5 \%(17)$ \\
\hline \multirow{2}{*}{$\begin{array}{l}\text { Couples with } \\
\text { school age } \\
\text { children }\end{array}$} & Fem & $0 \%(0)$ & $7.7 \%(2)$ & $0 \%(0)$ & $57.7 \%(15)$ & $34.6 \%(9)$ \\
\hline & Male & $0 \%(0)$ & $3.8 \%(1)$ & $0 \%(0)$ & $57.7 \%(15)$ & $38.5 \%(10)$ \\
\hline \multirow{2}{*}{$\begin{array}{l}\text { Couples with } \\
\text { Adolescent } \\
\text { children }\end{array}$} & Fem & $0 \%(0)$ & $2.6 \%(1)$ & $7.9 \%(3)$ & $60.5 \%(23)$ & $28.9 \%(11)$ \\
\hline & Male & $2.6 \%(1)$ & $2.6 \%(1)$ & $2.6 \%(1)$ & $55.3 \%(21)$ & $36.8 \%(14)$ \\
\hline \multirow{2}{*}{$\begin{array}{l}\text { Couples whose } \\
\text { children have } \\
\text { left home }\end{array}$} & Fem & $0 \%(0)$ & $12.5 \%(1)$ & $12.5 \%(1)$ & $75 \%$ (6) & $0 \%(0)$ \\
\hline & Male & $0 \%(0)$ & $12.5 \%(1)$ & $12.5 \%(1)$ & $62.5 \%(5)$ & $12.5 \%(1)$ \\
\hline \multirow{2}{*}{$\begin{array}{l}\text { Couples in old } \\
\text { age }\end{array}$} & Fem & $0 \%(0)$ & $0 \%(0)$ & $5.6 \%(1)$ & $77.8 \%(14)$ & $16.7 \%(3)$ \\
\hline & Male & $5.6 \%(1)$ & $0 \%(0)$ & $0 \%(0)$ & $55.6 \%(10)$ & $38.9 \%(7)$ \\
\hline \multirow{2}{*}{$\begin{array}{l}\text { Couples with adult } \\
\text { children } \\
\text { staying at home }\end{array}$} & Fem & $0 \%(0)$ & $4 \%(1)$ & $20 \%(5)$ & $52 \%(13)$ & $24 \%(6)$ \\
\hline & Male & $0 \%(0)$ & $4 \%(1)$ & $4 \%(1)$ & $64 \%(16)$ & $28 \%(7)$ \\
\hline \multirow{2}{*}{ Total } & Fem & $0 \%(0)$ & $0 \%(0)$ & 7.6\% (14) & $57.1 \%(105)$ & $32.1 \%$ (59) \\
\hline & Male & $1.1 \%(2)$ & $2.2 \%(4)$ & $3.2 \%(6)$ & $53.0 \%$ (98) & $40.5 \%(75)$ \\
\hline
\end{tabular}

Couples and men from the groups: Couple with adolescents (sig $=0.005)$, Couples whose children have left home (sig $=0.006)$ and Couples with adult children staying at home (sig $=0.010)$, revealing that childless men present a higher satisfaction than the others. There is a significant difference between men from Couples with young children and from Couples whose children have left home (sig $=0.043$ ), these last revealing a lower satisfaction.

We made an intra-group analysis, asserting within each group if there are significant differences between the degree of satisfaction of men and women (Table 4).

The existence of significant differences in satisfaction between men and women was observed only in the group Couples with young children, with the higher degree of satisfaction in men: in a large percentage of couples from this group man is happier than women (44\%), with $44 \%$ of couples with an identical level of happiness, 
Table 4. Degree of satisfaction with the relationship: comparison between female and male.

\begin{tabular}{ccccc}
\hline & $\begin{array}{c}\text { Satisfaction } \\
\text { Male }<\text { Fem }\end{array}$ & $\begin{array}{c}\text { Satisfaction } \\
\text { Male }>\text { Fem }\end{array}$ & $\begin{array}{c}\text { Satisfaction } \\
\text { male = Fem }\end{array}$ & Wilcoxon \\
\hline New Couples $(\mathrm{n}=30)$ & $16.66 \%(5)$ & $16.66 \%(5)$ & $66.66 \%(20)$ & $\mathrm{Z}=-0.00, p=1.00$ \\
Couples with young children $(\mathrm{n}=40)$ & $10 \%(4)$ & $30 \%(12)$ & $60 \%(24)$ & $\mathrm{Z}=-2.065, p=0.039^{*}$ \\
Couples with school age children $(\mathrm{n}=26)$ & $11.54 \%(3)$ & $19.23 \%(5)$ & $69.23 \%(18)$ & $\mathrm{Z}=-0.722, p=0.470$ \\
Couples with adolescent children ( $\mathrm{n}=38)$ & $23.68 \%(9)$ & $31.58 \%(12)$ & $44.74 \%(17)$ & $\mathrm{Z}=-0.399, p=0.735$ \\
Couples whose children have left home $(\mathrm{n}=8)$ & $25 \%(2)$ & $37.5 \%(3)$ & $37.5 \%(3)$ & $\mathrm{Z}=-0.276, p=0.783$ \\
Couples in old age (n=18) & $11.11 \%(2)$ & $33.33 \%(6)$ & $55.55 \%(10)$ & $\mathrm{Z}=-0.905, p=0.366$ \\
Couples with adult children still sating at home (n=25) & $12 \%(3)$ & $32 \%(8)$ & $56 \%(14)$ & $\mathrm{Z}=-1.184, p=0.236$ \\
Total $(\mathrm{n}=185)$ & $15.13 \%(28)$ & $27.57 \%(51)$ & $57.29 \%(106)$ & $\mathrm{Z}=-2.057, p=0.040^{*}$ \\
\hline
\end{tabular}

Note: *Significant to $p<0.05$.

and only $12 \%$ of couples in which the woman is happier than the man (Table 5).

The Anova One Way test detected significant differences for sig $\leq 0.01$ between the groups concerning intrinsic motivation in women, and did not reveal significant differences in the intrinsic motivation in men. We used a post-hoc test (LSD) in order to detect which groups of women differed in intrinsic motivation. This test revealed that the group of women from New Couples differs significantly from all other revealing higher intrinsic motivation (sig values between 0.05 and 0.001 ) (Table 6).

The Anova One Way test detected significant differences between groups for sig $\leq 0.01$ in women's perceived motivation of their partner. There were no significant differences in the perceived motivation in their wives. We used once again the post-hoc test (LSD) in order to detect which groups of women differed regarding the partner's perceived motivation. It revealed that women from New Couples differ significantly from all the others, perceiving a higher intrinsic motivation in partners (sig values between 0.043 and 0.001 ) (Table 7).

Student's T-test for dependent samples did not show, for sig for $<0.05$, the existence of significant differences in the intrinsic motivation between men and women in the different study groups (Table 8).

Student's T-test for dependent samples revealed the existence of significant differences between men and women in the perceived partners' motivation in two of the groups. In the group Couples with school age children and in the group Couples with adult children still staying at home the perceived motivation in partner by men is higher than the perceived motivation by woman in their partners (Table 9).

The Anova One Way test did not show, for sig for $<0.05$, the existence of significant differences in the extrinsic motivation between men and women in the different study groups (Table 10).

The Anova One Way test did not detect the existence of significant differences for sig $\leq 0.05$ between groups on grounds of extrinsic motivation partner, perceived by women and men (Table 11).

The t Student test for dependent samples showed significant differences sig for $<0.05$ in extrinsic motivationpersonal motives in the groups Couples with young children and Couples with school age children. In those groups men presented higher extrinsic personal motivation when compared with women (Table 12).

The t Student test for dependent samples showed, in all groups except for couples whose children have left home, the existence of significant or nearly significant differences for sig $<0.05$ between men and women, the extrinsic motivation perceived in partner. Extrinsic motivation perceived in partner is higher in males than in females (Table 13).

In females, it has been found a positive correlation with magnitude greater than 0.50 , significant or nearly significant, between intrinsic motivation-personal motives and satisfaction, in all groups except the couples in old age. The intrinsic motivation partner's motives, is also positively correlated, above 0.50 , with satisfaction in all groups except in couples who have adult children who have left home. As for extrinsic motivation-partner's motives, there was not a significant correlation with satisfaction in any group. In extrinsic motivation-personal motives, there is a significant positive correlation with satisfaction (although less than 0.50 magnitude) in only two groups: couples with adolescents and couples with adult children still staying at home (Table 14).

In males, we also found a positive correlation with a magnitude above 0.50 , significant or nearly significant, between intrinsic motivation-personal motives and satisfaction. This was true in all groups except the couples in 
Table 5. Intrinsic motivation personal reasons: comparison between the seven groups.

\begin{tabular}{|c|c|c|c|c|c|}
\hline & & $\mathrm{N}$ & Mean & $\begin{array}{c}\text { Std. } \\
\text { Deviation }\end{array}$ & $\begin{array}{l}\text { ONEWAY } \\
\text { ANOVA }\end{array}$ \\
\hline \multirow{8}{*}{$\begin{array}{c}\text { Intrinsic } \\
\text { Motivation-Personal } \\
\text { reasons (females) }\end{array}$} & New Couples & 30 & 79.40 & 11.40 & \multirow{8}{*}{$\begin{array}{l}F(6)=2.98 \\
\text { sig }=0.008^{*}\end{array}$} \\
\hline & Couples with young children & 40 & 70.39 & 15.37 & \\
\hline & Couples with school age children & 26 & 70.20 & 18.11 & \\
\hline & Couples with adolescent children & 38 & 70.35 & 18.14 & \\
\hline & Couples whose children have left home & 8 & 57.20 & 19.83 & \\
\hline & Couples in old age & 18 & 68.32 & 15.92 & \\
\hline & $\begin{array}{l}\text { Couples with adult children still } \\
\text { staying at home }\end{array}$ & 25 & 62.62 & 23.37 & \\
\hline & Total & 185 & 69.99 & 17.89 & \\
\hline \multirow{8}{*}{$\begin{array}{c}\text { Intrinsic } \\
\text { Motivation-Personal } \\
\text { reasons (males) }\end{array}$} & New Couples & 30 & 76.61 & 14.49 & \multirow{8}{*}{$\begin{array}{l}F(6)=1.450 \\
\text { sig }=0.198\end{array}$} \\
\hline & Couples with young children & 40 & 71.99 & 14.07 & \\
\hline & Couples with school age children & 26 & 73.57 & 15.57 & \\
\hline & Couples with adolescent children & 38 & 69.00 & 19.34 & \\
\hline & $\begin{array}{c}\text { Couples whose children have left } \\
\text { home }\end{array}$ & 8 & 63.45 & 16.75 & \\
\hline & Couples in old age & 18 & 67.71 & 10.99 & \\
\hline & $\begin{array}{l}\text { Couples with adult children still } \\
\text { staying at home }\end{array}$ & 25 & 68.76 & 14.13 & \\
\hline & Total & 185 & 71.12 & 15.57 & \\
\hline
\end{tabular}

Note: ${ }^{* *}$ sig $\leq 0.01$.

Table 6. Intrinsic motivation Partner’s Reasons: Comparison between the seven groups.

\begin{tabular}{|c|c|c|c|c|c|}
\hline & & $\mathrm{N}$ & Mean & $\begin{array}{l}\text { Std. } \\
\text { Deviation }\end{array}$ & $\begin{array}{l}\text { ONEWAY } \\
\text { ANOVA }\end{array}$ \\
\hline \multirow{8}{*}{$\begin{array}{c}\text { Intrinsic Motivation } \\
\text { Partner's-Motives } \\
\text { (females) }\end{array}$} & New Couples & 30 & 73.50 & 9.81 & \multirow{8}{*}{$\begin{array}{l}F(6)=3.115 \\
\operatorname{sig}=0.006^{* *}\end{array}$} \\
\hline & Couples with young children & 40 & 66.07 & 15.25 & \\
\hline & Couples with school age children & 26 & 62.43 & 15.11 & \\
\hline & Couples with adolescent children & 38 & 61.93 & 17.59 & \\
\hline & $\begin{array}{l}\text { Couples whose children have left } \\
\text { home }\end{array}$ & 8 & 51.90 & 10.79 & \\
\hline & Couples in old age & 18 & 62.15 & 17.04 & \\
\hline & $\begin{array}{l}\text { Couples with adult children still } \\
\text { staying at home }\end{array}$ & 25 & 60.47 & 19.91 & \\
\hline & Total & 185 & 64.16 & 16.31 & \\
\hline \multirow{8}{*}{$\begin{array}{l}\text { Intrinsic Motivation } \\
\text { Partner's-Motives } \\
\text { (males) }\end{array}$} & New Couples & 30 & 75.83 & 15.26 & \multirow{8}{*}{$\begin{array}{c}F(6)=1.386 \\
\text { sig }=0.223\end{array}$} \\
\hline & Couples with young children & 40 & 69.23 & 14.72 & \\
\hline & Couples with school age children & 26 & 72.00 & 16.28 & \\
\hline & Couples with adolescents children & 38 & 66.93 & 17.84 & \\
\hline & $\begin{array}{l}\text { Couples whose children have left } \\
\text { home }\end{array}$ & 8 & 61.31 & 17.36 & \\
\hline & Couples in old age & 18 & 70.71 & 17.13 & \\
\hline & $\begin{array}{l}\text { Couples with adult children still } \\
\text { staying at home }\end{array}$ & 25 & 69.50 & 14.15 & \\
\hline & Total & 185 & 70.06 & 16.09 & \\
\hline
\end{tabular}

Note: ${ }^{* *} \operatorname{sig} \leq 0.01$. 
Table 7. Intrinsic motivation personal reasons: female vs. male.

\begin{tabular}{|c|c|c|c|c|}
\hline & & $\begin{array}{c}\text { Intrinsic } \\
\text { Motivation-Personal } \\
\text { Motives (Female) }\end{array}$ & $\begin{array}{c}\text { Intrinsic } \\
\text { Motivation-Personal } \\
\text { Motives (Male) }\end{array}$ & $\begin{array}{l}\text { Paired Sample } \mathrm{t} \\
\text { test }\end{array}$ \\
\hline \multirow{2}{*}{ New Couples } & Mean & 79.40 & 76.61 & \multirow{2}{*}{$\begin{array}{l}\mathrm{t}(29)=1.013 \\
\text { sig }=0.320\end{array}$} \\
\hline & Std. Deviation & 11.40 & 14.49 & \\
\hline \multirow{2}{*}{ Couples with young children } & Mean & 70.39 & 71.99 & \multirow{2}{*}{$\begin{array}{l}t(39)=-0.61 \\
\text { sig }=0.543\end{array}$} \\
\hline & Std. Deviation & 15.37 & 14.07 & \\
\hline \multirow{2}{*}{ Couples with school age children } & Mean & 70.20 & 73.57 & \multirow{2}{*}{$\begin{array}{c}\mathrm{t}(25)=-1.262 \\
\text { sig }=0.219\end{array}$} \\
\hline & Std. Deviation & 18.11 & 15.57 & \\
\hline \multirow{2}{*}{ Couples with adolescent children } & Mean & 70.35 & 69.00 & \multirow{2}{*}{$\begin{array}{l}\mathrm{t}(37)=0.45 \\
\mathrm{sig}=0.653\end{array}$} \\
\hline & Std. Deviation & 18.14 & 19.34 & \\
\hline \multirow{2}{*}{$\begin{array}{l}\text { Couples whose children have left } \\
\text { home }\end{array}$} & Mean & 57.20 & 63.45 & \multirow{2}{*}{$\begin{array}{c}t(7)=-0.686 \\
\text { sig }=0.515\end{array}$} \\
\hline & Std. Deviation & 19.83 & 16.75 & \\
\hline \multirow{2}{*}{ Couples in old age } & Mean & 68.32 & 67.71 & \multirow{2}{*}{$\begin{array}{l}\mathrm{t}(17)=0.152 \\
\mathrm{sig}=0.881\end{array}$} \\
\hline & Std. Deviation & 15.92 & 10.99 & \\
\hline \multirow{2}{*}{$\begin{array}{l}\text { Couples with adult children still } \\
\text { staying at home }\end{array}$} & Mean & 62.62 & 68.76 & \multirow{2}{*}{$\begin{array}{c}t(24)=-1.352 \\
\text { sig }=189\end{array}$} \\
\hline & Std. Deviation & 23.37 & 14.13 & \\
\hline \multirow{2}{*}{ Total } & Mean & 70.01 & 71.66 & \multirow{2}{*}{$\begin{array}{c}\mathrm{t}(184)=-0.869 \\
\text { sig }=0.386\end{array}$} \\
\hline & Std. Deviation & 18.29 & 15.93 & \\
\hline
\end{tabular}

Note: $\operatorname{sig} \leq 0.05$.

Table 8. Intrinsic motivation partner’s motives: female vs. male.

\begin{tabular}{|c|c|c|c|c|}
\hline & & $\begin{array}{c}\text { Intrinsic } \\
\text { Motivation-Personal } \\
\text { Motives (Female) }\end{array}$ & $\begin{array}{c}\text { Intrinsic } \\
\text { Motivation-Personal } \\
\text { Motives (Male) }\end{array}$ & $\begin{array}{c}\text { Paired Sample t } \\
\text { test }\end{array}$ \\
\hline \multirow{2}{*}{ New Couples } & Mean & 73.50 & 75.83 & \multirow{2}{*}{$\begin{array}{l}t(29)=-0.937 \\
\operatorname{sig}=0.356\end{array}$} \\
\hline & Std. Deviation & 9.81 & 15.26 & \\
\hline \multirow{2}{*}{ Couples with young children } & Mean & 66.07 & 69.23 & \multirow{2}{*}{$\begin{array}{l}\mathrm{t}(39)=-1.116 \\
\operatorname{sig}=0.271\end{array}$} \\
\hline & Std. Deviation & 15.25 & 14.72 & \\
\hline \multirow{2}{*}{ Couples with school age children } & Mean & 62.43 & 72.00 & \multirow{2}{*}{$\begin{array}{l}t(25)=-3.204 \\
\operatorname{sig}=0.004^{* *}\end{array}$} \\
\hline & Std. Deviation & 15.11 & 16.28 & \\
\hline \multirow{2}{*}{ Couples with adolescent children } & Mean & 61.93 & 66.93 & \multirow{2}{*}{$\begin{array}{c}t(37)=-1.949 \\
\operatorname{sig}=0.059\end{array}$} \\
\hline & Std. Deviation & 17.59 & 17.84 & \\
\hline \multirow{2}{*}{$\begin{array}{l}\text { Couples whose children have left } \\
\text { home }\end{array}$} & Mean & 51.90 & 61.31 & \multirow{2}{*}{$\begin{aligned} t(7) & =-1.990 \\
\operatorname{sig} & =0.087\end{aligned}$} \\
\hline & Std. Deviation & 10.79 & 17.36 & \\
\hline \multirow{2}{*}{ Couples in old age } & Mean & 62.15 & 70.71 & \multirow{2}{*}{$\begin{array}{c}t(17)=-1.839 \\
\operatorname{sig}=0.083\end{array}$} \\
\hline & Std. Deviation & 17.04 & 17.13 & \\
\hline \multirow{2}{*}{$\begin{array}{l}\text { Couples with adult children still } \\
\text { staying at home }\end{array}$} & Mean & 60.47 & 69.50 & \multirow{2}{*}{$\begin{array}{l}\mathrm{t}(24)=-2.971 \\
\operatorname{sig}=0.007^{* *}\end{array}$} \\
\hline & Std. Deviation & 19.91 & 14.15 & \\
\hline \multirow{2}{*}{ Total } & Mean & 64.62 & 70.61 & \multirow{2}{*}{$\begin{array}{l}t(184)=-2.025 \\
\operatorname{sig}=0.04^{*}\end{array}$} \\
\hline & Std. Deviation & 16.63 & 16.39 & \\
\hline
\end{tabular}


Table 9. Extrinsic motivation personal motives: comparisons between the seven groups.

\begin{tabular}{|c|c|c|c|c|c|}
\hline & & $\mathrm{N}$ & Mean & $\begin{array}{c}\text { Std. } \\
\text { Deviation }\end{array}$ & $\begin{array}{l}\text { ONEWAY } \\
\text { ANOVA }\end{array}$ \\
\hline \multirow{8}{*}{$\begin{array}{c}\text { Extrinsic } \\
\text { motivation-Personal } \\
\text { reasons (Females) }\end{array}$} & New couples/Couples without children & 30 & 32,194 & 20,267 & \multirow{8}{*}{$\begin{array}{c}F(6)=1.965, \\
\text { sig }=0.073\end{array}$} \\
\hline & Couples with young children & 40 & 26,989 & 16,682 & \\
\hline & Couples with school age children & 26 & 32,740 & 18,201 & \\
\hline & Couples with adolescent children & 38 & 41,019 & 22,192 & \\
\hline & Couples whose children have left home & 8 & 35,312 & 13,911 & \\
\hline & Couples in old age & 18 & 39,790 & 19,739 & \\
\hline & Couples with adult children staying at home & 25 & 36,182 & 23,734 & \\
\hline & New couples/Couples without children & 30 & 38,203 & 23,298 & \\
\hline \multirow{8}{*}{$\begin{array}{c}\text { Extrinsic } \\
\text { motivation-Personal } \\
\text { reasons (Males) }\end{array}$} & Couples with young children & 40 & 40,423 & 21,603 & \multirow{8}{*}{$\begin{array}{c}F(6)=0.440 \\
\text { sig }=0.852\end{array}$} \\
\hline & Couples with school age children & 26 & 42,719 & 20,999 & \\
\hline & Couples with adolescent children & 38 & 40,972 & 22,615 & \\
\hline & Couples whose children have left home & 8 & 47,413 & 16,759 & \\
\hline & Couples in old age & 18 & 40,216 & 17,322 & \\
\hline & Couples with adult children staying at home & 25 & 35,772 & 21,433 & \\
\hline & New couples/Couples without children & 30 & 32,194 & 20,267 & \\
\hline & Couples with young children & 40 & 26,989 & 16,682 & \\
\hline
\end{tabular}

Note: sig $<0.05$.

Table 10. Extrinsic motivation partners motives: comparison between the seven groups.

\begin{tabular}{|c|c|c|c|c|c|}
\hline & & $\mathrm{N}$ & Mean & $\begin{array}{c}\text { Std. } \\
\text { Deviation }\end{array}$ & $\begin{array}{l}\text { ONEWAY } \\
\text { ANOVA }\end{array}$ \\
\hline \multirow{8}{*}{$\begin{array}{c}\text { Extrinsic } \\
\text { Motivation-Partners } \\
\text { Reasons (Female) }\end{array}$} & New couples/Couples without children & 30 & 32,361 & 19,845 & \multirow{8}{*}{$\begin{array}{c}F(6)=0.668 \\
\text { sig }=0.675\end{array}$} \\
\hline & Couples with young children & 40 & 30,906 & 17,985 & \\
\hline & Couples with school age children & 26 & 34,935 & 19,837 & \\
\hline & Couples with adolescent children & 38 & 39,050 & 21,070 & \\
\hline & Couples whose children have left home & 8 & 37,944 & 14,737 & \\
\hline & Couples in old age & 18 & 35,080 & 18,630 & \\
\hline & Couples with adult children staying at home & 25 & 33,509 & 22,459 & \\
\hline & New couples/Couples without children & 30 & 44,720 & 25,076 & \\
\hline \multirow{8}{*}{$\begin{array}{c}\text { Extrinsic } \\
\text { Motivation-Partners } \\
\text { Reasons (Male) }\end{array}$} & Couples with young children & 40 & 40,104 & 23,971 & \multirow{8}{*}{$\begin{array}{c}F(6)=0.592 \\
\text { sig }=0.736\end{array}$} \\
\hline & Couples with school age children & 26 & 49,082 & 21,204 & \\
\hline & Couples with adolescent children & 38 & 45,963 & 20,240 & \\
\hline & Couples whose children have left home & 8 & 39,915 & 8,332 & \\
\hline & Couples in old age & 18 & 46,917 & 14,893 & \\
\hline & Couples with adult children staying at home & 25 & 46,917 & 14,893 & \\
\hline & New couples/Couples without children & 30 & 32,361 & 19,845 & \\
\hline & Couples with young children & 40 & 30,906 & 17,985 & \\
\hline
\end{tabular}

Note: sig $<0.05$. 
Table 11. Extrinsic motivation personal motives-female vs. male.

\begin{tabular}{|c|c|c|c|c|}
\hline & & $\begin{array}{c}\text { Extrinsic } \\
\text { Motivation-Personal } \\
\text { Motives (Female) }\end{array}$ & $\begin{array}{c}\text { Extrinsic } \\
\text { Motivation-Personal } \\
\text { Motives (Male) }\end{array}$ & Paired Sample t test \\
\hline \multirow{2}{*}{ New Couples } & Mean & 32,194 & 38,203 & \multirow{2}{*}{$\begin{array}{l}\mathrm{t}(29)=-1.399 \\
\mathrm{sig}=0.172\end{array}$} \\
\hline & Std. Deviation & 20,266 & 23,298 & \\
\hline \multirow{2}{*}{ Couples with young children } & Mean & 26,989 & 40,423 & \multirow{2}{*}{$\begin{array}{l}\mathrm{t}(39)=-2.964 \\
\mathrm{sig}=0.005^{*}\end{array}$} \\
\hline & Std. Deviation & 16,682 & 21,603 & \\
\hline \multirow{2}{*}{ Couples with school age children } & Mean & 32,740 & 42,719 & \multirow{2}{*}{$\begin{array}{l}\mathrm{t}(25)=-2.209 \\
\quad \mathrm{sig}=0.037^{*}\end{array}$} \\
\hline & Std. Deviation & 18,201 & 20,999 & \\
\hline \multirow{2}{*}{ Couples with adolescent children } & Mean & 41,019 & 40,972 & \multirow{2}{*}{$\begin{array}{l}\mathrm{t}(37)=0.011 \\
\mathrm{sig}=0.991\end{array}$} \\
\hline & Std. Deviation & 22,192 & 22,615 & \\
\hline \multirow{2}{*}{$\begin{array}{l}\text { Couples whose children have left } \\
\text { home }\end{array}$} & Mean & 35,311 & 47,413 & \multirow{2}{*}{$\begin{array}{l}\mathrm{t}(7)=-1.724 \\
\mathrm{sig}=0.128\end{array}$} \\
\hline & Std. Deviation & 13,910 & 16,759 & \\
\hline \multirow{2}{*}{ Couples in old age } & Mean & 39,790 & 40,216 & \multirow{2}{*}{$\begin{aligned} \mathrm{t}(17) & =-0.065 \\
\mathrm{sig} & =0.949\end{aligned}$} \\
\hline & Std. Deviation & 19,739 & 17,322 & \\
\hline \multirow{2}{*}{$\begin{array}{l}\text { Couples with adult children still } \\
\text { staying at home }\end{array}$} & Mean & 32,194 & 38,203 & \multirow{2}{*}{$\begin{array}{l}\mathrm{t}(24)=0,090 \\
\mathrm{sig}=0,929\end{array}$} \\
\hline & Std. Deviation & 20,266 & 23,298 & \\
\hline \multirow{2}{*}{ Total } & Mean & 26,989 & 40,423 & \multirow{2}{*}{$\begin{array}{l}\mathrm{t}(29)=-1.399 \\
\mathrm{sig}\end{array}$} \\
\hline & Std. Deviation & 16,682 & 21,603 & \\
\hline
\end{tabular}

Note: ${ }^{*}$ sig $<0.05$.

Table 12. Extrinsic motivation partners motives-female vs. male.

\begin{tabular}{ccccc}
\hline & Mean & $\begin{array}{c}\text { Extrinsic } \\
\text { Motivation-Partners } \\
\text { Motives (Females) }\end{array}$ & $\begin{array}{c}\text { Extrinsic } \\
\text { Motivation-Partners } \\
\text { Motives (Males) }\end{array}$ & Paired Sample $\mathrm{t}$ test \\
\hline New Couples & Std. Deviation & 19,845 & 44,722 & $\mathrm{t}(29)=-2.203$, \\
Sig $=0.036^{*}$
\end{tabular}

Note: ${ }^{*}$ sig $<0.05 ;{ }^{* *}$ sig $<0.05 ;{ }^{* * *}$ sig $<0.05$. 
Table 13. Spearman correlation: motivation vs. satisfaction: females.

\begin{tabular}{|c|c|c|c|c|}
\hline & \multicolumn{4}{|c|}{ Females } \\
\hline & $\begin{array}{c}\text { Intrinsic Motivation } \\
\text { Correlation-Personal } \\
\text { Motives } \\
\text { Vs. } \\
\text { Satisfaction }\end{array}$ & $\begin{array}{c}\text { Extrinsic Motivation } \\
\text { Correlation-Personal } \\
\text { Motives } \\
\text { Vs. } \\
\text { Satisfaction }\end{array}$ & $\begin{array}{c}\text { Intrinsic Motivation } \\
\text { Correlation-Partners } \\
\text { Motives } \\
\text { Vs. } \\
\text { Satisfaction }\end{array}$ & $\begin{array}{c}\text { Extrinsic Motivation } \\
\text { Correlation-Partners } \\
\text { Motives } \\
\text { Vs. } \\
\text { Satisfaction }\end{array}$ \\
\hline $\begin{array}{l}\text { New couples/Couples } \\
\text { without children }\end{array}$ & $\begin{array}{c}\mathrm{R}=0.610 \\
p=0.000^{* * *} \\
\mathrm{~N}=30\end{array}$ & $\begin{array}{c}\mathrm{R}=0.083 \\
p=0.663 \\
\mathrm{~N}=30\end{array}$ & $\begin{array}{c}\mathrm{R}=0.586 \\
p=0.001^{* * *} \\
\mathrm{~N}=30\end{array}$ & $\begin{array}{c}\mathrm{R}=0.130 \\
p=0.494 \\
\mathrm{~N}=30\end{array}$ \\
\hline $\begin{array}{l}\text { Couples with young } \\
\text { children }\end{array}$ & $\begin{array}{c}\mathrm{R}=0.600 \\
p=0.000^{* * *} \\
\mathrm{~N}=40\end{array}$ & $\begin{array}{c}\mathrm{R}=0.216 \\
p=0.181 \\
\mathrm{~N}=40\end{array}$ & $\begin{array}{c}\mathrm{R}=0.454 \\
p=0.003^{* *} \\
\mathrm{~N}=40\end{array}$ & $\begin{array}{c}\mathrm{R}=-0.035 \\
p=0.494 \\
\mathrm{~N}=40\end{array}$ \\
\hline $\begin{array}{l}\text { Couples with school age } \\
\text { children }\end{array}$ & $\begin{array}{c}\mathrm{R}=0.705 \\
p=0.000^{* * *} \\
\mathrm{~N}=26\end{array}$ & $\begin{array}{c}\mathrm{R}=0.335 \\
p=0.094 \\
\mathrm{~N}=26\end{array}$ & $\begin{array}{l}\mathrm{R}=0.485 \\
p=0.012^{*} \\
\mathrm{~N}=\end{array}$ & $\begin{array}{c}\mathrm{R}=0.302 \\
p=0.134 \\
\mathrm{~N}=26\end{array}$ \\
\hline $\begin{array}{l}\text { Couples with adolescent } \\
\text { children }\end{array}$ & $\begin{array}{c}\mathrm{R}=0.641 \\
p=0.000^{* * *} \\
\mathrm{~N}=38\end{array}$ & $\begin{array}{c}\mathrm{R}=0.329 \\
p=0.040^{*} \\
\mathrm{~N}=38\end{array}$ & $\begin{array}{c}\mathrm{R}=0.663 \\
p=0.000^{* * *} \\
\mathrm{~N}=38\end{array}$ & $\begin{array}{c}\mathrm{R}=0.265 \\
p=0.107 \\
\mathrm{~N}=38\end{array}$ \\
\hline $\begin{array}{l}\text { Couples whose children } \\
\text { have left home }\end{array}$ & $\begin{array}{c}\mathrm{R}=0.655 \\
p=0.07 \\
\mathrm{~N}=8\end{array}$ & $\begin{aligned} \mathrm{R} & =0.502 \\
p & =0.205 \\
\mathrm{~N} & =8\end{aligned}$ & $\begin{array}{c}\mathrm{R}=-0.156 \\
p=0.712 \\
\mathrm{~N}=8\end{array}$ & $\begin{array}{c}\mathrm{R}=-0.655 \\
p=0.078 \\
\mathrm{~N}=8\end{array}$ \\
\hline Couples in old age & $\begin{array}{c}\mathrm{R}=0.302 \\
p=0.223 \\
\mathrm{~N}=18\end{array}$ & $\begin{array}{c}\mathrm{R}=0.100 \\
p=0.693 \\
\mathrm{~N}=18\end{array}$ & $\begin{array}{l}\mathrm{R}=0.550 \\
p=0.018^{*} \\
\mathrm{~N}=18\end{array}$ & $\begin{array}{c}\mathrm{R}=0.03 \\
p=0.897 \\
\mathrm{~N}=18\end{array}$ \\
\hline $\begin{array}{l}\text { Couples with adult } \\
\text { children staying at home }\end{array}$ & $\begin{array}{c}\mathrm{R}=0.673 \\
p=0.000^{* * *} \\
\mathrm{~N}=25\end{array}$ & $\begin{array}{c}\mathrm{R}=0.468 \\
p=0.018^{*} \\
\mathrm{~N}=25\end{array}$ & $\begin{array}{c}\mathrm{R}=0.606 \\
p=0.001^{* * *} \\
\mathrm{~N}=25\end{array}$ & $\begin{array}{c}\mathrm{R}=0.186 \\
p=0.374 \\
\mathrm{~N}=25\end{array}$ \\
\hline
\end{tabular}

Note: ${ }^{*}$ sig $<0.05 ;{ }^{* *}$ sig $<0.05 ;{ }^{* * *}$ sig $<0.05$.

Table 14. Spearman correlation: motivation vs. satisfaction: males.

\begin{tabular}{|c|c|c|c|c|}
\hline & \multicolumn{4}{|c|}{ Males } \\
\hline & $\begin{array}{c}\text { Intrinsic Motivation } \\
\text { Correlation-Personal } \\
\text { Motives } \\
\text { Vs. } \\
\text { Satisfaction }\end{array}$ & $\begin{array}{c}\text { Extrinsic Motivation } \\
\text { Correlation-Personal } \\
\text { Motives } \\
\text { Vs. } \\
\text { Satisfaction }\end{array}$ & $\begin{array}{c}\text { Intrinsic Motivation } \\
\text { Correlation-Partners } \\
\text { Motives } \\
\text { Vs. } \\
\text { Satisfaction }\end{array}$ & $\begin{array}{c}\text { Extrinsic Motivation } \\
\text { Correlation-Partners } \\
\text { Motives } \\
\text { Vs. } \\
\text { Satisfaction }\end{array}$ \\
\hline $\begin{array}{l}\text { New couples/Couples } \\
\text { without children }\end{array}$ & $\begin{array}{c}\mathrm{R}=0.549 \\
p=0.002^{* *} \\
\mathrm{~N}=30\end{array}$ & $\begin{array}{c}\mathrm{R}=0.329 \\
p=0.076 \\
\mathrm{~N}=30\end{array}$ & $\begin{array}{c}\mathrm{R}=0.468 \\
p=0.009^{* *} \\
\mathrm{~N}=30\end{array}$ & $\begin{array}{c}\mathrm{R}=0.197 \\
p=0.296 \\
\mathrm{~N}=30\end{array}$ \\
\hline $\begin{array}{l}\text { Couples with young } \\
\text { children }\end{array}$ & $\begin{array}{c}\mathrm{R}=0.497 \\
p=0.001^{* * *} \\
\mathrm{~N}=40\end{array}$ & $\begin{array}{c}\mathrm{R}=0.203 \\
p=0.209 \\
\mathrm{~N}=40\end{array}$ & $\begin{array}{c}\mathrm{R}=0.354 \\
p=0.025^{*} \\
\mathrm{~N}=40\end{array}$ & $\begin{array}{c}\mathrm{R}=0.244 \\
p=0.128 \\
\mathrm{~N}=40\end{array}$ \\
\hline $\begin{array}{l}\text { Coupes with school age } \\
\text { children }\end{array}$ & $\begin{array}{c}\mathrm{R}=0.600 \\
p=0.001^{* * *} \\
\mathrm{~N}=26\end{array}$ & $\begin{array}{c}\mathrm{R}=0.070 \\
p=0.734 \\
\mathrm{~N}=26\end{array}$ & $\begin{array}{c}\mathrm{R}=0.626 \\
p=0.001^{* * *} \\
\mathrm{~N}=26\end{array}$ & $\begin{array}{c}\mathrm{R}=0.152 \\
p=0.459 \\
\mathrm{~N}=26\end{array}$ \\
\hline $\begin{array}{l}\text { Couples with adolescent } \\
\text { children }\end{array}$ & $\begin{array}{l}\mathrm{R}=0.717 \\
p=0.000^{* * *} \\
\mathrm{~N}=38\end{array}$ & $\begin{array}{c}\mathrm{R}=0.202 \\
p=0.223 \\
\mathrm{~N}=38\end{array}$ & $\begin{array}{l}\mathrm{R}=0.605 \\
p=0.000^{* * *} \\
\mathrm{~N}=38\end{array}$ & $\begin{array}{c}\mathrm{R}=0.04 \\
p=0.810 \\
\mathrm{~N}=38\end{array}$ \\
\hline $\begin{array}{l}\text { Couples whose children } \\
\text { have left home }\end{array}$ & $\begin{array}{c}\mathrm{R}=0.873 \\
p=0.005^{* *} \\
\mathrm{~N}=8\end{array}$ & $\begin{array}{c}\mathrm{R}=0.288 \\
p=0.489 \\
\mathrm{~N}=8\end{array}$ & $\begin{array}{c}\mathrm{R}=0.873 \\
p=0.005^{* *} \\
\mathrm{~N}=8\end{array}$ & $\begin{array}{c}\mathrm{R}=-0.521 \\
p=0.185 \\
\mathrm{~N}=8\end{array}$ \\
\hline Couples in old age & $\begin{array}{c}\mathrm{R}=0.406 \\
p=0.095 \\
\mathrm{~N}=18\end{array}$ & $\begin{array}{c}\mathrm{R}=0.009 \\
p=0.971 \\
\mathrm{~N}=18\end{array}$ & $\begin{array}{c}\mathrm{R}=0.559 \\
p=0.016^{*} \\
\mathrm{~N}=18\end{array}$ & $\begin{array}{c}\mathrm{R}=0.205 \\
p=0.415 \\
\mathrm{~N}=18\end{array}$ \\
\hline $\begin{array}{l}\text { Couples with adult } \\
\text { children at home }\end{array}$ & $\begin{array}{c}\mathrm{R}=0.566 \\
p=0.003^{* *} \\
\mathrm{~N}=25\end{array}$ & $\begin{array}{l}\mathrm{R}=0.241 \\
p=0.247 \\
\mathrm{~N}=25\end{array}$ & $\begin{array}{c}\mathrm{R}=0.422 \\
p=0.035^{*} \\
\mathrm{~N}=25\end{array}$ & $\begin{array}{c}\mathrm{R}=0.058 \\
p=0.784 \\
\mathrm{~N}=25\end{array}$ \\
\hline
\end{tabular}

Note: ${ }^{*}$ sig $<0.05 ;{ }^{* *}$ sig $<0.05 ;{ }^{* * *}$ sig $<0.05$. 
old age. The intrinsic motivation-partner's motives are also positively correlated, above 0.50 , with satisfaction in all groups except couples who have adult children who have left home where the correlation is significant although weaker (below 0.50).

As for extrinsic motivation, either for personal or partner's motives there was no significant correlation with satisfaction in any of the groups (Table 15).

In females, it was found a positive correlation with magnitude above or close to 0.50 , significant between intrinsic motivation-personal motives and happiness in all groups with the exception of couples whose children have left home and in old age. The intrinsic motivation-partner's motives also correlates positively (with correlations between 0.453 and 0.598 ) with happiness in all groups except for couples who have adult children who have left home.

As for extrinsic motivation-personal motives, there is a significant positive correlation above 0.50 with happiness only in the group with children of school age. In the group with teenagers, correlation is also significant although weak.

In extrinsic motivation-partner's motives, only the group with children of school age reveals a correlation with happiness (Table 16).

In males, it was found a significant positive correlation with magnitude between 0.42 and 0.87 , between intrinsic motivation-personal motives and happiness in all groups with the exception of couples in old age. The intrinsic motivation-partner's motives is also positively correlated with happiness, between 0.39 and 0.873 , in all groups with the exception of couples in old age.

As for extrinsic motivation, for both personal and partner's motives, there was not a significant correlation with happiness in any group.

\section{Discussion}

One of our aims was to study the motivation attending marriage life cycle. When looking at our sample, we came across interesting differences. Despite the fact that the generality of the sample presented higher levels of

Table 15. Spearman correlation: motivation vs happiness: female.

\begin{tabular}{|c|c|c|c|c|}
\hline & \multicolumn{4}{|c|}{ Females } \\
\hline & $\begin{array}{c}\text { Intrinsic Motivation } \\
\text { Correlation-Personal } \\
\text { Motives } \\
\text { Vs. } \\
\text { Happiness }\end{array}$ & $\begin{array}{c}\text { Intrinsic Motivation } \\
\text { Correlation-Personal } \\
\text { Motives } \\
\text { Vs. } \\
\text { Happiness }\end{array}$ & $\begin{array}{c}\text { Intrinsic Motivation } \\
\text { Correlation-Personal } \\
\text { Motives } \\
\text { Vs. } \\
\text { Happiness }\end{array}$ & $\begin{array}{c}\text { Intrinsic Motivation } \\
\text { Correlation-Personal } \\
\text { Motives } \\
\text { Vs. } \\
\text { Happiness }\end{array}$ \\
\hline $\begin{array}{l}\text { New couples/Couples } \\
\text { without children }\end{array}$ & $\begin{array}{c}\mathrm{R}=0.479 \\
p=0.007^{* *} \\
\mathrm{~N}=30\end{array}$ & $\begin{array}{c}\mathrm{R}=0.338 \\
p=0.068 \\
\mathrm{~N}=30\end{array}$ & $\begin{array}{c}\mathrm{R}=0.453 \\
p=0.012^{*} \\
\mathrm{~N}=30\end{array}$ & $\begin{array}{c}\mathrm{R}=0.169 \\
p=0.080 \\
\mathrm{~N}=30\end{array}$ \\
\hline $\begin{array}{l}\text { Couples with young } \\
\text { children }\end{array}$ & $\begin{array}{c}\mathrm{R}=0.535 \\
p=0.000^{* * *} \\
\mathrm{~N}=40\end{array}$ & $\begin{array}{c}\mathrm{R}=0.243 \\
p=0.131 \\
\mathrm{~N}=40\end{array}$ & $\begin{array}{l}\mathrm{R}=0.453 \\
p=0.003^{* *} \\
\mathrm{~N}=40\end{array}$ & $\begin{array}{c}\mathrm{R}=-0.075 \\
p=0.647 \\
\mathrm{~N}=40\end{array}$ \\
\hline $\begin{array}{l}\text { Couples with school age } \\
\text { children }\end{array}$ & $\begin{array}{l}\mathrm{R}=0.552 \\
p=0.003^{* * *} \\
\mathrm{~N}=26\end{array}$ & $\begin{array}{c}\mathrm{R}=0.651 \\
p=0.000^{* * * *} \\
\mathrm{~N}=26\end{array}$ & $\begin{array}{l}\mathrm{R}=0.473 \\
p=0.015^{*} \\
\mathrm{~N}=26\end{array}$ & $\begin{array}{l}\mathrm{R}=0.468 \\
p=0.016^{*} \\
\mathrm{~N}=26\end{array}$ \\
\hline $\begin{array}{l}\text { Couples with adolescent } \\
\text { children }\end{array}$ & $\begin{array}{l}\mathrm{R}=0.560 \\
p=0.000^{* * *} \\
\mathrm{~N}=38\end{array}$ & $\begin{array}{c}\mathrm{R}=0.363 \\
p=0.025^{*} \\
\mathrm{~N}=38\end{array}$ & $\begin{array}{l}\mathrm{R}=0.598 \\
p=0.000^{* * *} \\
\mathrm{~N}=38\end{array}$ & $\begin{array}{c}\mathrm{R}=0.282 \\
p=0.086 \\
\mathrm{~N}=38\end{array}$ \\
\hline $\begin{array}{l}\text { Couples whose children } \\
\text { have left home }\end{array}$ & $\begin{array}{l}\mathrm{R}=0.630 \\
p=0.094 \\
\mathrm{~N}=8\end{array}$ & $\begin{array}{c}\mathrm{R}=0.507 \\
p=0.200 \\
\mathrm{~N}=8\end{array}$ & $\begin{array}{c}\mathrm{R}=-0.126 \\
p=0.766 \\
\mathrm{~N}=8\end{array}$ & $\begin{array}{c}\mathrm{R}=-0.630 \\
p=0.09 \\
\mathrm{~N}=8\end{array}$ \\
\hline Couples in old age & $\begin{array}{c}\mathrm{R}=0.261 \\
p=0.296 \\
\mathrm{~N}=18\end{array}$ & $\begin{array}{c}\mathrm{R}=0.038 \\
p=0.882 \\
\mathrm{~N}=18\end{array}$ & $\begin{array}{c}\mathrm{R}=0.499 \\
p=0.035^{*} \\
\mathrm{~N}=18\end{array}$ & $\begin{array}{c}\mathrm{R}=0.011 \\
p=0.967 \\
\mathrm{~N}=18\end{array}$ \\
\hline $\begin{array}{l}\text { Couples with adult } \\
\text { children staying at home }\end{array}$ & $\begin{array}{c}\mathrm{R}=0.636 \\
p=0.001^{* * *} \\
\mathrm{~N}=25\end{array}$ & $\begin{array}{l}\mathrm{R}=0.423 \\
p=0.035 \\
\mathrm{~N}=25\end{array}$ & $\begin{array}{c}\mathrm{R}=0.504 \\
p=0.010^{* *} \\
\mathrm{~N}=25\end{array}$ & $\begin{array}{c}\mathrm{R}=0.128 \\
p=0.541 \\
\mathrm{~N}=25\end{array}$ \\
\hline
\end{tabular}

Note: ${ }^{*}$ sig $<0.05 ;{ }^{* *}$ sig $<0.05 ;{ }^{* * *}$ sig $<0.05$. 
Table 16. Spearman correlation: motivation vs. happiness: males.

\begin{tabular}{|c|c|c|c|c|}
\hline & \multicolumn{4}{|c|}{ Males } \\
\hline & $\begin{array}{c}\text { Intrinsic Motivation } \\
\text { Correlation-Personal } \\
\text { Motives } \\
\text { Vs. } \\
\text { Happiness }\end{array}$ & $\begin{array}{c}\text { Intrinsic Motivation } \\
\text { Correlation-Personal } \\
\text { Motives } \\
\text { Vs. } \\
\text { Happiness }\end{array}$ & $\begin{array}{c}\text { Intrinsic Motivation } \\
\text { Correlation-Personal } \\
\text { Motives } \\
\text { Vs. } \\
\text { Happiness }\end{array}$ & $\begin{array}{c}\text { Intrinsic Motivation } \\
\text { Correlation-Personal } \\
\text { Motives } \\
\text { Vs. } \\
\text { Happiness }\end{array}$ \\
\hline $\begin{array}{l}\text { New Couples/Couples } \\
\text { without children }\end{array}$ & $\begin{array}{c}\mathrm{R}=0.419 \\
p=0.021^{*} \\
\mathrm{~N}=30\end{array}$ & $\begin{array}{c}\mathrm{R}=0.226 \\
p=0.229 \\
\mathrm{~N}=30\end{array}$ & $\begin{array}{l}\mathrm{R}=0.456 \\
p=0.011^{*} \\
\mathrm{~N}=30\end{array}$ & $\begin{array}{c}\mathrm{R}=0.112 \\
p=0.557 \\
\mathrm{~N}=30\end{array}$ \\
\hline $\begin{array}{l}\text { Couples with young } \\
\text { children }\end{array}$ & $\begin{array}{c}\mathrm{R}=0.558 \\
p=0.000^{* * *} \\
\mathrm{~N}=40\end{array}$ & $\begin{array}{c}\mathrm{R}=0.233 \\
p=0.149 \\
\mathrm{~N}=40\end{array}$ & $\begin{array}{c}\mathrm{R}=0.399 \\
p=0.011^{*} \\
\mathrm{~N}=40\end{array}$ & $\begin{array}{c}\mathrm{R}=0.171 \\
p=0.291 \\
\mathrm{~N}=40\end{array}$ \\
\hline $\begin{array}{l}\text { Couples with school age } \\
\text { children }\end{array}$ & $\begin{array}{c}\mathrm{R}=0.654 \\
p=0.000^{* * * *} \\
\mathrm{~N}=26\end{array}$ & $\begin{array}{c}\mathrm{R}=0.223 \\
p=0.274 \\
\mathrm{~N}=26\end{array}$ & $\begin{array}{c}\mathrm{R}=0.719 \\
P=0.000^{* * * *} \\
\mathrm{~N}=26\end{array}$ & $\begin{array}{c}\mathrm{R}=-0.014 \\
p=0.948 \\
\mathrm{~N}=26\end{array}$ \\
\hline $\begin{array}{l}\text { Couples with adolescent } \\
\text { children }\end{array}$ & $\begin{array}{c}\mathrm{R}=0.646 \\
p=0.000^{* * *} \\
\mathrm{~N}=38\end{array}$ & $\begin{array}{c}\mathrm{R}=0.145 \\
p=0.384 \\
\mathrm{~N}=38\end{array}$ & $\begin{array}{l}\mathrm{R}=0.569 \\
p=0.000^{* * *} \\
\mathrm{~N}=\end{array}$ & $\begin{array}{c}\mathrm{R}=-0.025 \\
p=0.882 \\
\mathrm{~N}=38\end{array}$ \\
\hline $\begin{array}{c}\text { Couples whose children } \\
\text { have left home }\end{array}$ & $\begin{array}{l}\mathrm{R}=0.873 \\
p=0.005^{* *} \\
\mathrm{~N}=8\end{array}$ & $\begin{aligned} \mathrm{R} & =0.288 \\
p & =0.489 \\
\mathrm{~N} & =8\end{aligned}$ & $\begin{array}{l}\mathrm{R}=0.873 \\
p=0.005^{* *} \\
\mathrm{~N}=8\end{array}$ & $\begin{array}{c}\mathrm{R}=-0.521 \\
p=0.185 \\
\mathrm{~N}=8\end{array}$ \\
\hline Couples in old age & $\begin{array}{c}\mathrm{R}=0.300 \\
p=0.227 \\
\mathrm{~N}=8\end{array}$ & $\begin{array}{c}\mathrm{R}=-0.044 \\
p=0.864 \\
\mathrm{~N}=8\end{array}$ & $\begin{array}{c}\mathrm{R}=0.306 \\
p=0.217 \\
\mathrm{~N}=8\end{array}$ & $\begin{array}{c}\mathrm{R}=-0.105 \\
p=0.678 \\
\mathrm{~N}=8\end{array}$ \\
\hline $\begin{array}{c}\text { Couples with adult } \\
\text { children staying at home }\end{array}$ & $\begin{array}{c}\mathrm{R}=0.456 \\
p=0.02^{*} \\
\mathrm{~N}=25\end{array}$ & $\begin{array}{c}\mathrm{R}=0.163 \\
p=0.438 \\
\mathrm{~N}=25\end{array}$ & $\begin{array}{l}\mathrm{R}=0.497 \\
p=0.012^{*} \\
\mathrm{~N}=25\end{array}$ & $\begin{array}{c}\mathrm{R}=0.120 \\
p=0.569 \\
\mathrm{~N}=25\end{array}$ \\
\hline
\end{tabular}

Note: ${ }^{*}$ sig $<0.05 ;{ }^{* *}$ sig $<0.05 ;{ }^{* * *}$ sig $<0.05$.

schooling, when an inner-gender analysis is made, women in the older groups (Couples whose children have left home, Couples in old age and Couples with adult children staying at home) presented lower qualifications. This shows a change in women's roles in the Portuguese society, since the 50's/60's when men were still seen as the family financial providers, in a more consistent manner, while women were educated in a more traditional sense, having the role of household keeper and mother. Nowadays, there is a higher tendency for both parents to have higher schooling levels and financial stability aiming at the improvement of couple's life. Women spend more years studying, and more time working outside the home, decreasing the time for the family. Therefore, parenthood tends to be delayed, and the number of children tends to be lower. According with Rogers and Amato (2000), recent marriages have a more equity features that oldest marriages.

Analysing the results concerning the development of motivation along life cycle, we can see that globally men's intrinsic and extrinsic motivation, both personal and perceived, tends to be unchangeable. In women, only intrinsic motivation, both personal and perceived, experience alterations decreasing after childbirth. Children appear to be a decreasing factor of intrinsic motivation for the mothers, possibly because the birth of a child is an important aspect in couple's life; the new family member will introduce important changes in the family system, especially for mothers.

A specific comparison between genders within each stage showed several differences worthy of note. Men’s motivation towards the relationship presented a more extrinsic base in the first years of parenthood, maybe due to the changes created in the dyadic system by the birth of the first child, causing women to be less available to the husband, as well as, presenting less erotic investment. On the other hand, with the growth of the family, extrinsic factors, like the role of family provider, or the concern with economic investments or even with a professional career may raise and influence the men's extrinsic motivation. The fact that men perceived their wives more extrinsically motivated in the first stages of marriage, seems to reflect the men's own motivation in those periods, influencing the way they perceive their spouses motivation, probably due to their ambivalence and struggles with the increasing of his role and responsibility towards the now enlarged family (Carter \& McGoldrick, 1989). Once more, men in old age couples showed also an increasing in perception of spouse's extrinsic values maybe due to changes that occur in this stage of life resulting from the aging process. 
Contrary to women, men presented less congruence between perceived and personal motivation. These results do not meet those by Rempel et al. (1985), which defended congruence between personal and perceived motivation, highlighting that our personal motivation influences the way we perceive our partner's motivation. As expected, wives personal and perceived motivation was congruent in all groups, since the women's own motivation style is the only predictor of her perceived motivation (Leslie \& Anderson, 1988).

In what concern marital satisfaction, the majority of the sample had satisfactory values between satisfied and very satisfied for both genders. However, marital satisfaction is a complex variable when considering men and women across the different stages. It is important to underline that both genders presented a decrease in satisfaction after childbirth.

Globally marital satisfaction appears to be mostly influenced by intrinsic motivation, either personal as perceived; however, some exceptions can be identified. In couples with adolescent children, besides being related with intrinsic motivation, women's satisfaction showed a significant influence of extrinsic personal motives. These data suggest a need to cope with difficulties of the stage, increasing the importance of personal extrinsic motivation to maintain the levels of satisfaction. In older couples, besides extrinsic motivation, intrinsic personal motives are not important for marital satisfaction, for both partners. Therefore, these results raise the hypothesis that the progressive dependence feature of this stage of life, will lead to a decreasing of the relation between marital satisfaction and intrinsic motivation.

The analyses of the data related with happiness, revealed that globally the sample presented levels lying between happy and very happy for both genders. However, men and women presented a decrease in happiness after childbirth. A more accurate analysis of gender within the different groups showed that only when adult children are still at home, men are happier than women.

For the majority of the groups and in both genders, happiness is mainly influenced by intrinsic motivation, both personal and perceived. Our results are, therefore, congruent with the idea that people are happier the more intrinsic and autonomous their motivation is (Sheldon et al., 2004). However, some exceptions can be pointed. For women the importance of external motives suffers an increase when children reach school age and adolescence. Despite the importance of all motivation styles, the results reflect a rising of the value of extrinsic motive to compensate a decrease of importance of intrinsic motivation, possibly related with the increase of cost (financial, of time and psychological) inherent to those stages of life. Old age couples show a decreasing in the relation between happiness and motivation, maybe related with the crises and features of the life's stage: decrease of the autonomy, increase of loneliness and loss of significant others, changes in status and stability.

\section{Conclusion}

During the marriage cycle, men and women's motivations do not suffer large fluctuations, considering only a decrease in women's intrinsic motivation both personal and perceived. However, as we saw, small differences can be reported when comparing both genders within each group, mainly an increasing of men's extrinsic personal and perceived motivation especially in the first three stages of marriage.

For marital satisfaction, perceived motivation is as important as personal motivation, but only in what concerns intrinsic motives. Extrinsic motivations, both personal and perceived, have almost none influence over marital satisfaction. Women exhibit a higher variation in the relation between satisfaction and motivation, especially in long-term marriages. In men, only intrinsic motivation is related with marital satisfaction, not showing many variations across the marriage course. Thus, in long-term couples marital satisfaction is not influenced in the same way by motivation as in the early years, suggesting changes across marriage life cycle. Extrinsic factors seem not to have the same effect in women than in men, especially when children are adolescents or adults living home. The crises triggered by the departure of the children and the empty nest will also lead to the decreasing of intrinsic factors influence on satisfaction.

Regarding happiness, the data show that for both men and women's marital happiness, perceived and personal motivations are important, but only in what concerns intrinsic motives. Extrinsic motivations, both personal and perceived, have almost no influence over marital happiness, taking part only in two stages of the marriage course. However, when compared with men, women exhibit more inconstant standards across the marriage, being the only gender whose happiness is related with intrinsic motivation in some point in the marriage. Extrinsic motives appear to have a determined role in wives' happiness after children start school and across adolescence. In men, only intrinsic motivation is related with marital happiness, not showing many variations across marriage 
course. Nonetheless, an increase of the relation between happiness and motivation can be pointed until adulthood is reached. If the adult children stay at home, the relation happiness-satisfaction will present similar levels to those exhibited in the early years of marriage. But, when children leave home, a progressive decreasing is evident, primarily in the mothers and as the couple gets older also in the fathers. In a general overview, happiness seems to be a broader concept since the results of this variable are less complex than those concerning satisfaction. However, a simplistic reading of the results, allows seeing that in our first two stages of marriage (Couples without children and Couples with young children) satisfaction and happiness are only influenced by intrinsic motivation. On the other hand, extrinsic motivation showed a higher importance in happiness when children reach school age and adolescence. For satisfaction, extrinsic motives are only important to couples with adolescent children and for couples with adult children at home. A decrease in the importance of extrinsic and intrinsic motivation in satisfaction and happiness can be seen in the latest years of marriage.

One of the most interesting groups contemplated in our study was couples with adult children still living at home; to our knowledge, few investigations have addressed this issue. For that reason and being an increasingly frequent situation, this new stage of couples' life seems to be important to develop in future research.

However, our results raised other questions, which are as well important and interesting to develop in future studies. For once, it will be interesting to understand if perceived and personal motivations are congruent in all stages of the marriage life, and between genders.

In this work, we came across a marriage stage that in studies of our knowledge is not yet contemplated, —adult children living at home. For that reason, it seems important to develop further researches on this new phase.

\section{References}

Abreu-Afonso, J., \& Leal, I. (2009). Escala de Motivação: Adaptação e validação da Motivation Scale (M.S.) de Rempel, Holmes \& Zanna. Psicologia, Saúde \& Doenças, 10, 249-266. http://repositorio.ispa.pt/handle/10400.12/1092

Aimé, A., Sabourim, S., \& Valois, P. (2000). L’appariement des styles de motivation et 1'evolution de la satisfaction conjugale. Revue Canadienne des Sciences du Comportement, 32, 178-186. http://dx.doi.org/10.1037/h0087114

Aron, A., Aron., E., \& Norman, C. (2002). Self-Expansion Model of Motivation and Cognition in Close RELATIONSHIPS and Beyond. In G. J. O. Flecher, \& M. S. Clark (Eds.), Blackwell Handbook of Social Psychology: Interpersonal Process. (pp. 478-502). Cornwall: Blackwell Publishers.

Aron, A., Norman, C., Aron, E., McKenna, C., \& Heyman, R. (2000). Couples’ Shared Participation in Novel and Arousing Activities and Experienced Relationship Quality. Journal of Personality and Social Psychology, 78, 273-284.

http://dx.doi.org/10.1037/0022-3514.78.2.273

Bernstein, D. (1990). Of Carrots and Sticks: A Review of Deci and Rayan's Intrinsic Motivation and Self-Determination in Human Behaviour. Journal of the Experimental Analysis of Behaviour, 54, 323-332. http://dx.doi.org/10.1901/jeab.1990.54-323

Blais, M., Sabourin, S., Boucher, C., \& Vallerand, R. (1990). Toward a Motivational Model of Couple Happiness. Journal of Personality and Social Psychology, 59, 1021-1031. http://dx.doi.org/10.1037/0022-3514.59.5.1021

Carter, B., \& McGoldrick, M. (1989). The Changing Family Life-Cycle: A Framework to Family Therapy (2nd ed.). Boston, MA: Ally \& Bacon

Deci, E. L. \& Ryan, R. M. (2008). Facilitating Optimal Motivation and Psychological Well-Being across Life’s Domains. Canadian Psychology, 49, 14-23. http://dx.doi.org/10.1037/0708-5591.49.1.14

Deci, E. L., Koestner, R., \& Ryan, R. M. (1999). A Meta-Analytic Review of Experiments Examining the Effects of Extrinsic Rewards on Intrinsic Motivation. Psychological Bulletin, 125, 627-626. http://dx.doi.org/10.1037/0033-2909.125.6.627

Deci, E., \& Ryan, R. (2000). The "What” and "Why” of Goal Pursuits: Human Needs and Self-Determination of Behaviour. Psychological Inquiry, 11, 227-268. http://dx.doi.org/10.1207/S15327965PLI1104_01

Deci, E.L. \& Ryan, R.M. (1985). Intrinsic Motivation and Self-Determination in Human Behaviour. New York: Plenum. http://dx.doi.org/10.1007/978-1-4899-2271-7

DeHart, T., Pelham, B., Fiedorowicz, L., Carvallo, M., \& Gabriel, S. (2011). Including Others in the Implicit Self: Implicit Evaluation of Significant Others. Self and Identity, 10, 127-135. http://dx.doi.org/10.1080/15298861003687880

Gable, S., \& Impett, E. (2012). Approach and Avoidance Motives and Close Relationships. Social and Personality Compass, 6, 95-108. http://dx.doi.org/10.1111/j.1751-9004.2011.00405.x 
Gaine, G., \& La Guardia, J. (2009). The Unique Contributions of Motivations to Maintain a Relationship and Motivations toward Relational Activities to Relationship Well-Being. Motivation \& Emotion, 33, 184-202. http://dx.doi.org/10.1007/s11031-009-9120-x

Haley, J. (1984). Un Thérapeute hors du commun, Milton Erickson. Paris: ÉPI.

Impett, E., Gable, S., \& Peplau, A. (2005). Giving up and Giving in: The Cost and Benefits of Daily Sacrifice in Intimate Relationships. Journal of Personality and Social Psychology, 89, 327-344. http://dx.doi.org/10.1037/0022-3514.89.3.327

Impett, E., Gordon, A., Kogan, A., Oveis, C., Gable, S., \& Keltner, D. (2010). Moving toward More Perfect Unions: Daily and Long-Term Consequences of Approach and Avoidance Goals in Romantic Relationship. Journal of Personality and Social Psychology, 99, 948-963. http://dx.doi.org/10.1037/a0020271

Knee, R., Patrick, H., Vietor, N., Nanayakkara, A., \& Neighbors, C. (2002). Self-Determination as Growth Motivation in Romantic Relationships. Personality and Social Psychology Bulletin, 28, 609-619. http://dx.doi.org/10.1177/0146167202288005

Kogan, A., Impett, E., Oveis, C., Hui, B., Gordon, A., \& Keltner, D. (2010). When Gives Feels Good: The Intrinsic Benefits of Sacrifice in Romantic Relationships for the Communally Motivated. Psychological Science, 21, 1918-1924. http://dx.doi.org/10.1177/0956797610388815

La Guardia, J., \& Patrick, H. (2008). Self-Determination Theory as a Fundamental Theory of Close Relationships. Canadian Psychology, 49, 201-209. http://dx.doi.org/10.1037/a0012760

Leslie, L. A., \& Anderson, E. A. (1988). Men’s and Women’s Participation in Domestic Roles: Impact on Quality of Life and Marital Adjustments. Journal of Family Psychology, 2, 212-226. http://dx.doi.org/10.1037/h0080494

Li, T., \& Fung, H. (2011). The Dynamic Goal Theory of Marital Satisfaction. Review of General Psychology, 15, $246-254$. http://dx.doi.org/10.1037/a0024694

Mayer, J. D., Faber, M. A., \& Xu, X. (2007). Seventy-Five Years of Motivation Measures (1930-2005): A Descriptive Analysis. Motivation and Emotion, 31, 83-103. http://dx.doi.org/10.1007/s11031-007-9060-2

Murray, S. (2005). Regulating the Risk of Closeness: A Relationship-Specific Sense of Felt Security. Current Directions in Psychological Science, 14, 74-78. http://dx.doi.org/10.1111/j.0963-7214.2005.00338.x

Neighbourgh, R. H. (1985). The Family Life-Cycle. Journal of the Royal Society of Medicine, 78, 11-15. http://www.ncbi.nlm.nih.gov/pmc/articles/PMC1289511/

Patrick, H., Knee, C. R., Lonsbary, C., \& Canevello, A. (2007) The Role of Need Fulfillment in Relationship Functioning and Well-Being: A Self-Determination Theory Perspective. Journal of Personality and Social Psychology, 92, 434-457. http://dx.doi.org/10.1037/0022-3514.92.3.434

Relvas, A. P. (2004). O ciclo vital da família-Perspectiva sistémica. Porto: Edições Afrontamento.

Rempel, J. K., Holmes, J. G., \& Zanna, M. P. (1985). Trust in Close Relationships. Journal of Personality and Social Psychology, 49, 95-112. http://dx.doi.org/10.1037/0022-3514.49.1.95

Rogers, S. J., \& Amato, P. R. (2000). Have Changes in Gender Relations Affected Marital Quality? Social Forces, 79, 731753. http://dx.doi.org/10.1093/sf/79.2.731

Ryan, R. M., \& Deci, E. (2000). Intrinsic and Extrinsic Motivations: Classic Definitions and New Directions. Contemporary Educational Psychology, 25, 54-67. http://dx.doi.org/10.1006/ceps.1999.1020

Seligman, C., Fazio, R. H., \& Zanna, M. P. (1980). Effects of Salience of Extrinsic Rewards on Liking and Loving. Journal of Personality and Social Psychology, 38, 453-460. http://dx.doi.org/10.1037/0022-3514.38.3.453

Sheldon, K., Ryan, R., Deci, E., \& Kasser, T. (2004). The Independent Effect of Goal Contents and Motives on Well-Being: It’s Both What You Pursue and Why You Pursue It. Personality and Social Psychology Bulletin, 30, 475-486. http://dx.doi.org/10.1177/0146167203261883

Story, P. A., Hart, J. W., Stasson, M. F., \& Mahoney, J. M. (2009). Using a Two-Factor Theory of Achievement Motivation to Examine Performance-Based Outcomes and Self-Regulatory Processes. Personality and Individual Differences, 46, 391-395. http://dx.doi.org/10.1016/j.paid.2008.10.023

Vallerand, R. (2000). Deci and Ryan's Self-Determination Theory: A View from the Hierarchical Model of Intrinsic and Extrinsic Motivation. Psychological Inquiry, 11, 312-318.

http://web.a.ebscohost.com/ehost/pdfviewer/pdfviewer?vid=4\&sid=df5fe432-d677-41f8-8481-f14917ae7c67\%40sessionm gr4004\&hid=4104

Waldemar, J. O. C. (1998). Terapia de Casal. In A. V. Cordoli (Ed.), Psicoterapias-Abordagens Actuais. Porto Alegre: Artes Médicas. 